\title{
Taxonomy of Engineer-To-Order Companies
}

\author{
Pavan Kumar Sriram and Erlend Alfnes \\ Dept. of Production and Quality Engineering, \\ Norwegian University of Science and Technology, Trondheim, Norway \\ \{pavan.sriram, erlend.alfnes\} @ntnu.no
}

\begin{abstract}
In this paper taxonomy has been developed to classify the different forms of ETO firms to enable a like-with-like comparison, arguing that existing taxonomies within the literature are inadequate for production planning and control research purposes. Successful production planning and control concepts from high volume, low variety producers cannot be directly applied, because of the unique nature of ETO products. Secondly through synthesis of the literature and the analysis of the three case studies we describe and examine the production planning and control activities characteristics of the ETO environment to distinguish the different environment within ETO production.
\end{abstract}

Keywords: Production planning and control, engineer-to-order, empirical study and review.

\section{Introduction}

Aspects of globalization have stirred an increase in demand for customized products. While having a customized product the customers also expect the products to be manufactured and delivered in short time, at a nearly same cost as mass production with relatively high quality [1]. This market trend requires manufacturing companies to be able to rapidly and cheaply produce customized products with a required quality level. This requirement is somehow controversial with conventional understanding, i.e. a trade-off between customization and low cost through highly efficient production mode, such as mass production. On the other hand, this market trend also provides the manufacturing companies with new opportunities, particularly for these small or medium sized enterprises (SMEs) in developed countries like Norway. The typical examples are customized thruster manufacturers, heavy-duty lifting and material handling equipment companies, special industrial equipment manufacturers, etc. In these manufacturing businesses, the customers normally require the orders to be specified with their specific requirements and to be filled within a short lead-time [2]. The high customization and short lead-time drive the customers to place their orders with a local company instead of an overseas competitor. However, the high cost of producing a customized product through a traditional production mode, e.g. job shop, may turn the customers away from these local companies [3]. Therefore, to keep the high customization, short lead-time and at meanwhile to effectively reduce the production cost become the high priority strategy for manufacturing companies to effectively compete with overseas large and cheap producers [4]. This is particularly true for SMEs in the developed countries Norway.

B. Grabot et al. (Eds.): APMS 2014, Part III, IFIP AICT 440, pp. 579-587, 2014.

(C) IFIP International Federation for Information Processing 2014 
In this paper we focus upon different types of engineer-to-order companies and identify taxonomy that demonstrates the importance of the relationship between the degree of design activity, volume of manufacture, and of the distinction between products that are custom built from options, and those that involve custom design elements. This paper examines how these companies can effectively make use of the taxonomy to support management decision making in order to manage their manufacturing operations more effectively.

\section{Methodology}

The primary research methodology is multiple case study research, and by placing emphasis on the production planning and control (PPC) system framework of [5], we present empirical examples based on three companies operating within the heavy lift, crane \& barge, and aluminum casting industry in Norway. This is carried out in accordance with a case-based approach [6]. The cases are conducted using data collected through semi-structured interviews of several informants in the companies, including the managing director and production manager(s). Production planners were also involved in the discussions. Direct observations and the analysis of secondary sources, such as company documentation and corporate website are used for triangulation, to check the internal consistency of data [7]. The central idea is to constantly compare theory and data, iterating toward a theory which closely fits the data [8].

\section{Theoretical Background}

\subsection{Production Planning and Control}

In ETO firms the time needed for engineering may represent a significant part of the total lead time. [9] developed a novel planning and scheduling model for ETO sectors where the MRPII was not a good fit.[10], presented a new framework for MRP system to be effective in ETO. The system was developed to allow aggregate production planning coordination between engineering, material acquisition and production activities, as well as the information structures but did not focus on coordination with supply chain. [1], presented that production planning and control are the most critical tools to meet customer demands and most of the existing systems are based on the superficial software's and there is a need for industry specific design. Stevenson's work mainly focused on the applicability of classical approaches to PPC, and highlighted the importance of workload control (WLC) concept to make-to-order (MTO) companies. But the scope is limited to assessing the applicability of various existing approaches to PPC.

More authors looked on development of methods/models on integration of Enterprise resource planning (ERP), Supply chain management (SCM), and innovative process as they considered them to be key elements for a successful planning and control system $[11,12]$. But the frameworks don't address the effective planning of design, product configuration, and scheduling at different levels. And also it was focusing only on SCM in ETO and lacked applicability to various other planning and control issues in an ETO environment. [13], presented a concept for integrated manufacturing and innovative process in ETO environment. The work described a project 
management tool integration production planning. It highlighted the dependencies between logistics management and project management, but do not capture how to tackle planning and control in ETO in various stages of manufacturing. Also there have been both lean and agile strategies proposed in the ETO sector, wherein both paradigms attempt to rationalize tools, techniques, philosophies and approaches to manufacturing planning and control. But there are disagreements as to the boundaries, definitions and applicability of leanness and agility [4]. Also there are studies carried out by [14] shows a synergistic impact in combining the lean and ERP, but it is still not clear from the extant literature as to how either of these approaches can be successfully applied in ETO companies. [15], proposed a concept for an integrated planning and control conceptual framework based on 'seiban (meaning a manufacturing number in Japanese, is a technique for managing orders in the supply chain which is alternative to traditional MRP logic).' approach for project specific manufacturing, the main focus of the work was limited to development of a new ERP system. This work represents a fundamental difference in the information system requirements for MTS, ATO and ETO companies. A detailed literature on production planning and control approaches for ETO can be found in the article [15], in this paper we limit our discussions to the taxonomy. This paper aims to; briefly review the literature on the types of ETO companies based upon an analysis of literature review; distinguish ETO firms that provide a framework for identify similarities and differences between companies. This will be tested through a series of case studies as additional work.

\subsection{Definitions of ETO}

The increased number of academic articles on the topic of ETO is one example of the growing importance of the ETO concept. An overview of the number of the published articles shows that the research interest in the subject has been continually high over the past 5 years (source: EBSCO Business Source Premier Database). Although much has been published about ETO in the academic literature, commonly accepted definitions and frameworks have not yet been established. Many academic definitions exist, all of which differ in one or more aspects [4]. For this work we aim to develop a common comprehensive definition of the ETO concept, which will be deemed too broad to facilitate a common understanding in the work of the academics and of the industry research group on ETO: "Engineer-to-order (ETO) refers to a customer integrated process of unique products and services, which meet the needs of each individual customer with regard to certain product feature. All the operations are performed within a flexible solution space and high engineering responsive process".

\subsection{ETO Existing Typology/Taxonomy}

There are numerous articles presenting classification work in the field of ETO. To establish a more detailed understanding, a literature review of the existing classifications of ETO was conducted. Articles were first identified by using EBSCO and applying pre-defined search terms, through which we identified six articles presenting a classification of ETO. The details of the same are furnished in table 1. 


\begin{tabular}{|c|c|c|c|c|}
\hline Authors & Overview & $\begin{array}{c}\text { Research } \\
\text { Type }\end{array}$ & $\begin{array}{c}\text { Industry } \\
\text { Type }\end{array}$ & $\begin{array}{l}\text { Evaluation } \\
\text { Dimension }\end{array}$ \\
\hline $\begin{array}{l}\text { Gosling } \\
\text { and } \\
\text { Naim, } \\
\text { (2009) }\end{array}$ & $\begin{array}{l}\text { ETO is defined as a stan- } \\
\text { dard product range offered } \\
\text { with the added availability } \\
\text { of modifications and custo- } \\
\text { mizations. DTO, instead, is } \\
\text { defined as where new prod- } \\
\text { uct introductions with de- } \\
\text { sign, engineering and manu- } \\
\text { facturing based on new } \\
\text { customer orders. The two } \\
\text { manufacturing systems are } \\
\text { therefore clearly distin- } \\
\text { guished one from the other. } \\
\text { In addition ETO is divided, } \\
\text { in turn, in ETO and ETS } \\
\text { (engineer-to-stock). }\end{array}$ & $\begin{array}{l}\text { Concep- } \\
\text { tual }\end{array}$ & $\begin{array}{l}\text { Large and } \\
\text { complex } \\
\text { project in } \\
\text { sectors } \\
\text { such as } \\
\text { construc- } \\
\text { tion and } \\
\text { capital } \\
\text { goods, } \\
\text { film mak- } \\
\text { ing, ship- } \\
\text { building, } \\
\text { law cases } \\
\text { and soft- } \\
\text { ware de- } \\
\text { velopment }\end{array}$ & $\begin{array}{l}\text { Degree of } \\
\text { customer in- } \\
\text { volvement, } \\
\text { degree of } \\
\text { product cus- } \\
\text { tomization, } \\
\text { and the opera- } \\
\text { tions environ- } \\
\text { ment }\end{array}$ \\
\hline $\begin{array}{l}\text { JG } \\
\text { Wacker } \\
\text { and Mil- } \\
\text { ler, } \\
(2000)\end{array}$ & $\begin{array}{l}\text { ETO environment is divided } \\
\text { in two different categories: } \\
\text { configure to order and in- } \\
\text { vent to order. CTO consists } \\
\text { in making product very } \\
\text { similar to the previous ones } \\
\text { and first engineering task is } \\
\text { tailoring or configuring the } \\
\text { product to meet the custom- } \\
\text { er requirements. ITO needs } \\
\text { more engineering time in- } \\
\text { stead in inventing and de- } \\
\text { signing the product; in ITO } \\
\text { companies' previous prod- } \\
\text { ucts are rather different } \\
\text { from the current ones. }\end{array}$ & $\begin{array}{l}\text { Concep- } \\
\text { tual }\end{array}$ & $\begin{array}{l}\text { Buildings } \\
\text { construc- } \\
\text { tion }\end{array}$ & $\begin{array}{l}\text { Degree of } \\
\text { engineering } \\
\text { time product } \\
\text { customization, } \\
\text { and degree of } \\
\text { customer in- } \\
\text { volvement }\end{array}$ \\
\hline
\end{tabular}




\begin{tabular}{|c|c|c|c|c|}
\hline $\begin{array}{l}\text { Segers- } \\
\text { tedt and } \\
\text { Olofsson, } \\
(2010) \text {. }\end{array}$ & $\begin{array}{l}\text { Construction concepts and } \\
\text { projects also show different } \\
\text { preparations before the cus- } \\
\text { tomer order arrives and } \\
\text { before realization of the } \\
\text { project. The first and lowest } \\
\text { degree of a defined building } \\
\text { system is the well-known } \\
\text { engineer-to-order where } \\
\text { companies design products } \\
\text { in ordinary construction } \\
\text { projects. The design specifi- } \\
\text { cation process is mainly } \\
\text { based on client require- } \\
\text { ments, norms and standards. } \\
\text { Winch (2003) divided the } \\
\text { engineer-to-order further in } \\
\text { concept-to-order (CTO) and } \\
\text { design-to-order (DTO) re- } \\
\text { flecting the two main con- } \\
\text { tractual forms between the } \\
\text { client and the construction } \\
\text { company; design-build } \\
\text { and design-bid-build respec- } \\
\text { tively. }\end{array}$ & $\begin{array}{l}\text { Concep- } \\
\text { tual } \\
\text { (though } \\
\text { empiri- } \\
\text { cally } \\
\text { validated) }\end{array}$ & $\begin{array}{l}\text { Buildings } \\
\text { construction }\end{array}$ & $\begin{array}{l}\text { Degree of } \\
\text { product } \\
\text { customiza- } \\
\text { tion, and } \\
\text { degree of } \\
\text { customer } \\
\text { involvement }\end{array}$ \\
\hline $\begin{array}{l}\text { Hicks et } \\
\text { al., } \\
(2001)\end{array}$ & $\begin{array}{l}\text { Four ideal types of company } \\
\text { were developed to explain } \\
\text { how production processes } \\
\text { are organized within ETO } \\
\text { firms. } \\
\text { The variables used to } \\
\text { classify companies are the } \\
\text { depth of product structure, } \\
\text { which indicates product } \\
\text { complexity, and the volume } \\
\text { of production, which deter- } \\
\text { mines whether jobbing, } \\
\text { batch or flow processes are } \\
\text { employed. So type I is a } \\
\text { vertically integrated compa- } \\
\text { ny. Type II outsources } \\
\text { component manufacture, } \\
\text { but maintains assembly and } \\
\text { construction activities in- } \\
\text { house. Type III outsources } \\
\text { all physical processes. }\end{array}$ & $\begin{array}{l}\text { Concep- } \\
\text { tual } \\
\text { (though } \\
\text { empiri- } \\
\text { cally } \\
\text { validated) }\end{array}$ & $\begin{array}{l}\text { Capital } \\
\text { goods: de- } \\
\text { sign, manu- } \\
\text { facture and } \\
\text { construction } \\
\text { plant (Power } \\
\text { generation, } \\
\text { offshore, } \\
\text { power elec- } \\
\text { tronics and } \\
\text { instrumenta- } \\
\text { tion, material } \\
\text { handling, } \\
\text { power gener- } \\
\text { ation, distri- } \\
\text { bution and } \\
\text { utilization) }\end{array}$ & $\begin{array}{l}\text { Types of } \\
\text { process, and } \\
\text { depth of } \\
\text { product } \\
\text { structure }\end{array}$ \\
\hline
\end{tabular}




\begin{tabular}{|c|c|c|c|c|}
\hline $\begin{array}{l}\text { Wikner } \\
\text { and Rud- } \\
\text { berg, } \\
(2005)\end{array}$ & $\begin{array}{l}\text { ETO can be seen as a spe- } \\
\text { cial case of MTO. In both } \\
\text { cases the production flow is } \\
\text { driven by actual customer } \\
\text { orders. However, in the } \\
\text { ETO case both the design } \\
\text { and engineering activities } \\
\text { are driven by customer } \\
\text { orders, but these activities } \\
\text { are not parts of the produc- } \\
\text { tion flow. By doing this, a } \\
\text { production dimension cov- } \\
\text { ering the typical CODPPD, } \\
\text { is established. On the other } \\
\text { hand we get an engineering } \\
\text { dimension where the prod- } \\
\text { uct can be designed and } \\
\text { engineered based on cus- } \\
\text { tomer orders. }\end{array}$ & $\begin{array}{l}\text { Concep- } \\
\text { tual }\end{array}$ & $\begin{array}{l}\text { Generic } \\
\text { industry }\end{array}$ & $\begin{array}{l}\text { Degree of } \\
\text { customer } \\
\text { involve- } \\
\text { ment, and } \\
\text { degree of } \\
\text { product } \\
\text { customiza- } \\
\text { tion }\end{array}$ \\
\hline $\begin{array}{l}\text { Amaro et } \\
\text { al., } \\
(1999)\end{array}$ & $\begin{array}{l}\text { Arrives at four basic de- } \\
\text { gree of product customiza- } \\
\text { tion which also holds clas- } \\
\text { sification aspects of differ- } \\
\text { ent degrees of customer } \\
\text { involvement. The result of } \\
\text { the typology comprises of } \\
\text { three attributes and eleven } \\
\text { possible categories. The } \\
\text { empirical validation is } \\
\text { carried out through } 22 \\
\text { company case. }\end{array}$ & $\begin{array}{l}\text { Concep- } \\
\text { tual } \\
\text { (though } \\
\text { empiri- } \\
\text { cally } \\
\text { validated) }\end{array}$ & $\begin{array}{l}\text { Medical and } \\
\text { military } \\
\text { equipment, } \\
\text { polymer and } \\
\text { polymer } \\
\text { products, } \\
\text { magnets, } \\
\text { conveyors } \\
\text { and industri- } \\
\text { al automa- } \\
\text { tion, me- } \\
\text { chanical } \\
\text { assemblies } \\
\text { and switch- } \\
\text { gears }\end{array}$ & $\begin{array}{l}\text { Degree of } \\
\text { customer } \\
\text { involve- } \\
\text { ment, degree } \\
\text { of product } \\
\text { customiza- } \\
\text { tion, and } \\
\text { scope of } \\
\text { internal } \\
\text { responsibili- } \\
\text { ty/activities }\end{array}$ \\
\hline
\end{tabular}

\section{Towards Taxonomy for ETO Companies}

\section{Case Study}

Company A is an engineering company: that does project management (100\%), contracts, engineering (90\%, some is outsourced), doesn't have manufacturing at all (10\%, just follow-up). Installation on site is limited to supervision and control (ca 25\%). Mainly outsources low-cost production. Company A differentiates itself in the technology used in casting. Company $\mathrm{B}$ is an engineering and service company, and 
supplier of heavy-duty lifting and material handling equipment in a capacity range of 25 to 1000 tones and more. They develop designs, delivers, tests, commissions and carries out service on heavy lifting and material handling equipment for use in harsh and corrosive marine environments. Company $\mathrm{C}$ is a global supplier of marine structures with an innovative engineering- and expertise environment. The products are developed and marketed in collaboration with partner firms. They have established a long term co-operation with partners who are of the world's leading providers of ship design, marine equipment and complete system solutions. From the case studies, the significant differences between the three types of ETO are highlighted and elaborated. The differences found in the study are divided as distinguished features of ETO production environment.

Table 1. Distinguishing features of the ETO production environment in case companies

\begin{tabular}{|c|c|c|c|}
\hline Characteristics & Company A & Company B & Company $\mathbf{C}$ \\
\hline Product Design & $\begin{array}{l}\text { Custom built us- } \\
\text { ing standard mod- } \\
\text { ules }\end{array}$ & $\begin{array}{l}\text { Usually exclu- } \\
\text { sive to one } \\
\text { customer }\end{array}$ & Custom built \\
\hline Product Size & $\begin{array}{l}\text { Small and medium } \\
\text { size }\end{array}$ & Generally big & $\begin{array}{l}\text { Small and medium } \\
\text { size }\end{array}$ \\
\hline Product Change & Low & High & Medium \\
\hline Production Volume & $\begin{array}{l}\text { Medium to high } \\
\text { volume }\end{array}$ & $\begin{array}{l}\text { One to very low } \\
\text { volume }\end{array}$ & $\begin{array}{l}\text { Low to medium } \\
\text { volume }\end{array}$ \\
\hline Production planning & $\begin{array}{l}\text { Stable and some- } \\
\text { times dynamic }\end{array}$ & $\begin{array}{l}\text { Dynamic and } \\
\text { sometimes } \\
\text { chaotic }\end{array}$ & $\begin{array}{l}\text { Dynamic and } \\
\text { sometimes stable }\end{array}$ \\
\hline Labour Skills & $\begin{array}{l}\text { Little or no spe- } \\
\text { cialised skills } \\
\text { required }\end{array}$ & $\begin{array}{l}\text { Specialised } \\
\text { skills }\end{array}$ & $\begin{array}{l}\text { Some specialised } \\
\text { skills required }\end{array}$ \\
\hline $\begin{array}{l}\text { Major production } \\
\text { activity }\end{array}$ & $\begin{array}{l}\text { Assembly and } \\
\text { manufacturing }\end{array}$ & Assembly & $\begin{array}{l}\text { Assembly and } \\
\text { manufacturing }\end{array}$ \\
\hline $\begin{array}{l}\text { Customer input } \\
\text { during design }\end{array}$ & $\begin{array}{l}\text { Customer rarely } \\
\text { involved during } \\
\text { design }\end{array}$ & $\begin{array}{l}\text { Customer gives } \\
\text { input during } \\
\text { design }\end{array}$ & $\begin{array}{l}\text { Customer usually } \\
\text { give input during } \\
\text { design }\end{array}$ \\
\hline Inventory & Medium & Low & Medium \\
\hline $\begin{array}{l}\text { Supplier involve- } \\
\text { ment }\end{array}$ & Low & High & Medium \\
\hline Product Design & $\begin{array}{l}\text { Custom built us- } \\
\text { ing standard mod- } \\
\text { ules }\end{array}$ & $\begin{array}{l}\text { Usually exclu- } \\
\text { sive to one } \\
\text { customer }\end{array}$ & Custom built \\
\hline
\end{tabular}

\section{Conclusions}

One of the main impediments in the study of ETO has been the absence of constructs and the little distinction that has been made between the ETO product delivery strategy and the managerial and organizational style of the companies. Although many of 
types of ETO firms may have common characteristics, there are many important differences. Through case study we have tried to highlight the significant differences between three firms. The effectiveness of ETO planning and control unfortunately lags far behind the level of manufacturing planning and control practices in, for example, make-to-stock (MTS) or assemble-to-order (ATO) producers. Successful manufacturing planning and control concepts from high volume, low variety producers cannot be directly applied, because of the unique nature of ETO products. This paper presents a taxonomy of ETO firms that provides a framework for identify similarities and differences between firms. It also provides a framework that will help with the transfer of best manufacturing planning and control practices. Secondly there are numerous areas for research in production planning and control for ETO firms. One of the major weakness of previous research is that little has been done to document present industry practice in case studies or surveys. This lack of practical criteria makes a realistic evaluation of the relative merits of the previous research difficult. Research on the various aspects of production planning and control in ETO firms needs more attention. A framework for integrated models considering all facets of production planning and control is needed. Future research must be grounded with industrial data to ensure that it is relevant to actual concerns.

Acknowledgement. This research was made possible by the EFFEKT, LIFT and SUSPRO project as well as SFI Norman. The authors would like to thank the participants of the project for providing the inputs and fruitful discussions.

\section{References}

[1] Stevenson, M., Hendry, L.C., Kingsman, B.G.: A review of production planning and control: the applicability of key concepts to the make-to-order industry. International Journal of Production Research 43, 869-898 (2005)

[2] Amaro, G., Hendry, L., Kingsman, B.: Competitive advantage, customisation and a new taxonomy for non make-to-stock companies. International Journal of Operations \& Production Management 19, 349-371 (1999)

[3] Hicks, C., McGovern, T., Earl, C.F.: A typology of UK engineer-toorder companies. Int. J. Logis. Res. and Appl. 4, 43-56 (2001)

[4] Gosling, J., Naim, M.M.: Engineer-to-order supply chain management: A literature review and research agenda. International Journal of Production Economics 122, 741-754 (2009)

[5] Vollmann, T.E., Berry, W.L., Whybark, D.C., Jacobs, R.F.: Manufacturing Planning and Control for Supply Chain Management. McGraw-Hill, Boston (2005)

[6] Voss, C.A., Tsikriktsis, N., Frohlich, M.: Case Research in Operations Management. International Journal of Operations \& Production Management 22, 195-210 (2002)

[7] Scandura, T.A., Williams, E.A.: Research methodology in management: Current practices, trends, and implications for future research. Academy of Management Journal, 1248-1264 (2000)

[8] Eisenhardt, K.M.: Building Theories from Case Study Research. Academy of Management: The Academy of Management Review 14, 532-549 (1989) 
[9] Little, D., Rollins, R., Peck, M., Porter, J.K.: Integrated planning and scheduling in the engineer-to-order sector. International Journal of Computer Integrated Manufacturing 13, $545-554$ (2000)

[10] Jin, G., Thomson, V.: A new framework for MRP systems to be effective in engineeredto-order environments. Robotics and Computer-Integrated Manufacturing 19, 533-541 (2003)

[11] McGovern, T.O.M., Hicks, C., Earl, C.F.: Modelling Supply Chain Management Processes in Engineer-to-Order Companies. International Journal of Logistics Research and Applications 2, 147-159 (1999)

[12] Samaranayake, P., Toncich, D.: Integration of production planning, project management and logistics systems for supply chain management. International Journal of Production Research 45, 5417-5447 (2007)

[13] Caron, F., Fiore, A.: Engineer to order' companies: how to integrate manufacturing and innovative processes. International Journal of Project Management 13, 313-319 (1995)

[14] Powell, D., Olesen, P.: ERP Systems for Lean Production Control. presented at the 13th International Conference on Modern Information Technology in the Innovation Processes of Industrial Enterprises (MITIP), Norwegian University of Science and Technology, Trondheim, Norway (2011)

[15] Sriram, P.K., Alfnes, E., Arica, E.: A Concept for Project Manufacturing Planning and Control for Engineer-to-Order Companies. In: Emmanouilidis, C., Taisch, M., Kiritsis, D. (eds.) Advances in Production Management Systems. Competitive Manufacturing for Innovative Products and Services, pp. 699-706. Springer, Heidelberg (2013) 